\title{
STUDIES ON THE PRODUCTION OF $\alpha$ - AMYLASE BY Bacillus subtilis
}

\author{
HARIKRISHNA YADAV. NANGANURU ${ }^{1}$, NARASIMHULU. KORRAPATI ${ }^{2}$, \\ SATISH. MUTYALA ${ }^{3}$ \\ ${ }^{1}$ (Department of Biotechnology, National Institute of Technology, Warangal, India. \\ ${ }^{2}$ (Department of Biotechnology, National Institute of Technology, Warangal, India. \\ ${ }^{3}$ (Department of Biological sciences, Swinburne University of Technology, Melbourne, Australia.
}

\begin{abstract}
Cell growth of Bacillus subtilis and the production of $\alpha$-amylase in the medium were examined. Based on the amylase productivity level in shake flask cultures after 72 hours of growth, the growth medium containing starch and peptone was selected as the best medium.

Our results show that the amylase production is higher in the presence of optimum Carbon and Nitrogen ratio. The production of the enzyme was maximum $(370 \mathrm{U} / \mathrm{mg}$ ) at $72 \mathrm{~h}$ after inoculation. The effect of incubation period, $\mathrm{pH}$ of the medium and incubation temperature was optimized. The maximum production of enzyme was obtained at $30^{\circ} \mathrm{C}$ and $\mathrm{pH}$.
\end{abstract}

KEYWORDS:- $\alpha$ - amylase, Bacillus subtilis, Batch cultures, Enzyme production, Growth.

\section{INTRODUCTION}

Enzymes are protein molecules, which are necessary for life. Amylases are enzymes that break down complex carbohydrates. There are different sources to produce amylases. Plants, animals and microbes can produce amylases [1]. These enzymes account for about $30 \%$ of the world's enzyme production and have a great significance with extensive biotechnological applications in bread and baking, food, textile, and paper industries [2,3]. Today, amylases are available commercially in the large number and they have almost completely replaced chemical hydrolysis of starch processing and reduce the production of chemicals used in carbohydrate hydrolysis. Microorganisms produce different kinds of industrial enzymes. Because of their biochemical diversity and the ease with environmental and genetic manipulation, they have replaced enzymes, which traditionally have been isolated from complex eukaryotes [4]. Bacillus subtilis is one of the most widely used bacteria for the production of specific chemicals and industrial enzymes and also a major source of amylase and protease enzymes. [5,6] The major advantage of using microorganisms for production of amylases is in economical bulk production capacity and microbes are also easy to manipulate to obtain enzymes of desired characteristics [1]. There are some factors, which influence the nature of their metabolic process and the enzyme production. The composition and concentration of media and physical parameters greatly affect the growth and production of extracellular amylase in bacteria [7]. Optimization of cultural conditions is important for maximum production of microbial strains [8]. Bacillus species and other forms of microorganisms grow at different rates with specificity to different substrates in the culture medium. The growth conditions also influence their enzymatic activities [9]. The present work describes the batch culture production of $\alpha$ amylase by Bacillus subtilis under controlled conditions.

\section{MATERIAL AND METHODOLOGY}

Bacillus subtilis Cultures were obtained from Microbial Type Culture Collection. In this study, the cultures were grown in water soluble medium containing Beef extract, Yeast extract, Peptone, and $\mathrm{NaCl}$. Production media containing equal volumes of carbon and nitrogen source was taken in flask. The inoculum was taken $1 \%$ of the production media size. The cells were inoculated into nutrient broth and incubated at $30^{\circ} \mathrm{C}$ for $48 \mathrm{~h}$. These cells were transferred to micro centrifuge tubes and centrifuged at $4000 \mathrm{rpm}$ for $15 \mathrm{~min}$. Supernatant was separated from cell debris and used as the crude enzyme. Bernfeld procedure was used to determine amylase activity. Samples were taken at 3, 6, 12, 24, 32, 48, 60, 72, 84, and $96 \mathrm{~h}$. The reaction mixture containing $200 \mu \mathrm{l}$ of $1 \%$ substrate (w/v) in $0.1 \mathrm{M}$ phosphate buffer and $150 \mu \mathrm{l}$ of enzyme solution was incubated for $30 \mathrm{~min}$ at $30^{\circ} \mathrm{C}$. The reaction was stopped by adding $400 \mu \mathrm{l}$ of 3,5-dinitrosalicylic acid solution. Then this mixture was heated in a boiling water bath and cooled at room temperature to develop brown colour. $8 \mathrm{ml}$ of deionized water was added to this solution. Then the absorbance was measured at $540 \mathrm{~nm}$ with a spectrophotometer. 


\section{RESULTS AND DISCUSSION}

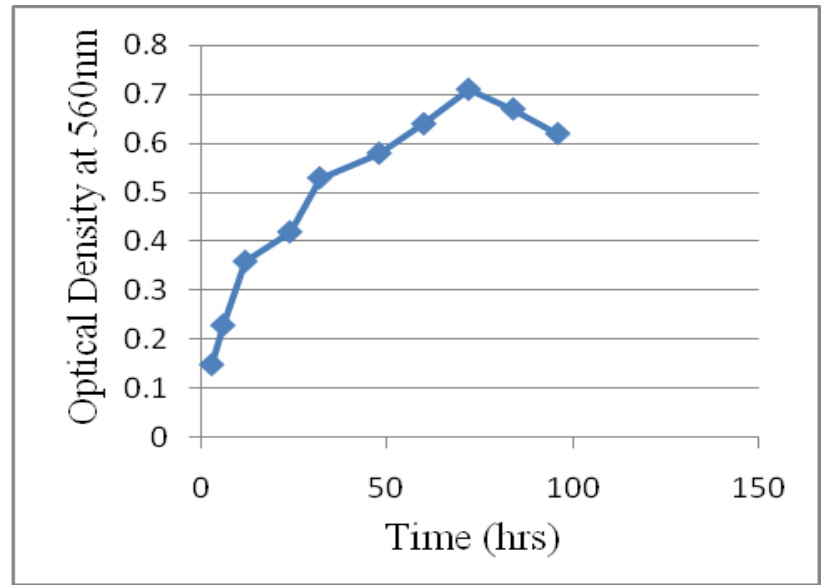

Figure 1: Growth of Bacillus subtilis with respect to Time (hrs)

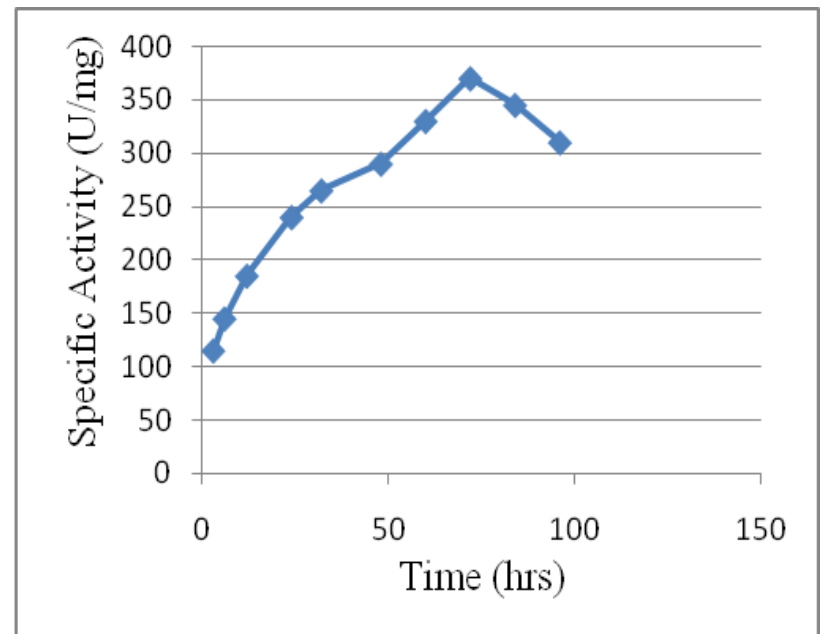

Figure 2 Production of $\alpha$-amylase by Bacillus subtilis with respect to Time (hrs)

Optimization of culture conditions is very important for maximum microbial growth and enzyme production by microbial strains. So optimization of growth condition is a prime step in fermentation technology [10]. In the present study we observed $30^{\circ} \mathrm{C}$ and 7 as the optimum growth temperature and $\mathrm{pH}$ respectively. This could be due to the mesophilic nature of the Bacillus subtilis. But high temperatures and $\mathrm{pH}$ may inactivate the expression of gene responsible for the starch degrading enzyme [11]. Among the physiological parameters, optimum temperature, substrate concentration and $\mathrm{pH}$ range are the most important for enzyme production by microbes [12,13]. Most of the starch degrading bacterial strain revealed a $\mathrm{pH}$ range between 6.0 and 7.0 for normal growth and enzyme activity[13]. Presently, this B. subtilis strain also showed maximum growth in this optimum range. The results of the time-course studies on cell growth of $B$. subtilis grown in media are shown in Fig 1. Maximum growth is shown at $72 \mathrm{hrs} \mathrm{(Fig} \mathrm{1).} \mathrm{The} \mathrm{nature} \mathrm{and} \mathrm{amount} \mathrm{of} \mathrm{carbon} \mathrm{and} \mathrm{nitrogen} \mathrm{sources} \mathrm{in}$ culture media are also important for the growth and production of extracellular amylase in bacteria along with the physical parameters $[14,15]$. The levels of amylase in the crude culture supernatants varied greatly in response to the carbon and nitrogen source used for the growth of the B. subtilis strain. The maximal growth rate and production of extracellular amylase was obtained when the strain was grown in media. Peptone in media promoted $\alpha$-amylase productivity. The main advantage of growing $B$. subtilis on this medium for amylase production is the very fast production time[16, 17, 18]. Amylase production is greatly reduced when glutamate or citrate is used and the amylase production is maximum when starch is used as a carbon source [19, 20,21]. The growth and production of extracellular amylase production in bacteria can be affected by the composition and concentration of media [22]. Enzyme production by $B$. subtilis is directly correlated to the time period of incubation [23]. The present study observed enhanced enzyme activity with the increase in incubation time. The production of amylase was reached maximum of $370 \mathrm{U} / \mathrm{mg}$ at $72 \mathrm{~h}$ of incubation period (Fig. 2). Further increase in incubation period did not show any significant increase in enzyme production rather it was decreased. Thus optimum time of enzyme synthesis was to be $72 \mathrm{hrs}$ after inoculation. The enzyme production was initiated at about $6 \mathrm{~h}$ in the media 
containing 1.0\% soluble starch [24]. Our results indicated that the optimum incubation period for amylase production was 72 h (Fig. 2). Enzyme production gradually declined after $72 \mathrm{hrs}$. In this experiment, the maximum $\alpha$-amylase production occurred when optical cell population reached its peak. Amylase production by B. subtilis was found to be growth-associated as the maximum enzyme production was observed during the beginning of stationary phase, when the Optical Density reached a plateau. The production of enzyme was directly related to the growth of the B. subtilis.

\section{CONCLUSION}

The optimal physical conditions, concentration and composition of Nitrogen and Carbon sources are very important for studying growth of $B$. subtilis and the $\alpha$-amylase production. The maximum $\alpha$-amylase $370 \mathrm{U} / \mathrm{mg}$ was produced during batch fermentation in shaking flask in $72 \mathrm{hrs}$ of growth. The production of the enzyme was directly related to the growth of the strain. Maximum enzyme activity was obtained at the beginning of the stationary growth phase.

\section{REFERENCES}

[1] Aiyer PV (2004). Effect of C:N ratio on alpha amylase production by Bacillus licheniformis SPT 27. Afr. J. Biotechnol. 3: 519-522.

[2] Sivaramakrishnan S, Gangadharan D, Nampoothiri KM, Soccol CR, Pandey A: $\alpha$ -Amylases from microbial sources-an Overview on recent developments. Food Technol Biotechnol, 44, 173-184, 2006.

[3] Gupta R, Gigras P, Mohapatra H, Goswami VK, Chauhan B: Microbial $\alpha$-amylases: A biotechnological perspective. Process Biochem, 38, 1599-1616, 2003

[4] Pandey, A., P. Nigam, C.R. Soccol, V.T. Soccol, D. Singh and R. Mohan, 2000. Advances in microbial amylases. Biotechnol. Appl. Biochem., 31: 135-152.

[5] Anwar A, Saleemudin M (2000). Alkaline protease from spilosoma oblique: potential application in bioformulation. Biotechnology and Appl. Biochem. 31 (2): 85-89.

[6] Gupta R, Beg QK, Lorenz P(2002). Bacterial alkaline proteases: molecular approaches and industrial applications. Appl. Microbiol. and Biotechnol. 59 (1): 15-32.

[7] R. A. K. Srivastava, J. N. Baruah, Appl. Environ. Microbiol. 52 (1986) 179

[8] R. L. Bezbaruah, B. K. Gogoi, K. R. Pilla, J. Basic Microbiol. 34 (1994) 139

[9] A. O. Ajayi, O. E. Fagade, Afr. J. Biotechnol. 5 (2006) 440

[10] Kathiresan K, Manivannan S (2006). a-amylase production by Penicillium fellutanum isolated from mangrove rhizospheric soil. Afr. J. Biotechnol. 5: 829-832

[11] Aiba S, Kitai K, Imanaka T (1983). Cloning and Expression of Thermostable _ $\alpha-$ Amylase Gene from Bacillus stearothermophilus in Bacillus stearothermophilus and Bacillus subtilis. Appl. Environ. Microbiol. 46: 1059-1065.

[12] Bose K, Das D (1996). Thermostable a-amylase production using B.licheniformis NRRL B1438. Indian J. Exp. Biol. 34: 1279-1282.

[13] Gupta R, Gigras P, Mohapatra H, Goswami VK, Chauhan B (2003). Microbial aamylases: a biotechnological prospective. Process Biochem. 38: 1599-1616.

[14] A. Pandey, P. Nigam, C. R. Soccol, V. T. Soccol, D. Singh, R. Mohan, Biotechnol. Appl Biochem. 31 (2000) 135

[15] P. V. Dharani Aiyer, Afr. J. Biotechnol. 3 (2004) 519

[16] E. de O. Santos, M. L. L. Martins, Braz. Arch. Biol. Technol. 48 (2003) 129

[17] M. Asgher, M. Javaid Asad, S. U. Rahman, R. L. Legge, J. Food Eng. 79 (2007) 950

[18] N. Goyal, J. K. Gupta, S. K. Soni, Enzyme Microb. Technol. 37 (2005) 723

[19] L. L. Lin, M. R. Tsau, W. S. Chu, Appl. Microbiol. Biotechnol. 42 (1994) 51

[20] R. K. Saxena, K. Dutt, L. Agarwal, P. Nayyar, Bioresour. Technol. 98 (2007) 260

[21] T. E. El-Banna, A. A. Abd-Aziz, M. I. Abou-Dobara, R. I. Ibrahim, Pak. J. Biol. Sci. 10 (2007) 2039

[22] Chandra AK, Medda S, Bhadra AK (1980). Production of extracellular thermostable aamylase by Bacillus lichenifermis. J. Ferment. Technol. 58: 1-10.

[23] Smitt JP, Rinzema J, Tramper H, Van M, Knol W (1996). Solid state fermentation of wheat bran by Trichoderma reesei QMQ414. Appl. Microbial. Biotechnol. 46: 489-496.

[24] Lehninger, A.L., 1982. Biochemistry. Worth Pub. Inc. USA 